\title{
FORUM
}

Invited article

DOI: http://dx.doi.org/10.1590/So034-759020170602

\section{JOINING THE SOCIOMATERIAL DEBATE}

\section{MARLEI POZZEBON}

marlei.pozzebon@hec.ca Professor at HEC Montréal, Department of International Business - Montréal - Québec, Canada and Fundação Getulio Vargas, Escola de Administração de Empresas de São Paulo - São Paulo-SP, Brazil

EDUARDO HENRIQUE DINIZ eduardo.diniz@fgv.br Professor at Fundação Getulio Vargas, Escola de Administração de Empresas de São Paulo - São Paulo-SP, Brazil

\section{NATHALIE MITEV} nmitev@btinternet.com Senior Visiting Research Fellow at King's College London, Department of Management London, UK

FRANÇOIS-XAVIER DE VAUJANY devaujany@dauphine.fr Professor at l'Université ParisDauphine - Paris, France

MIGUEL PINA E CUNHA mpc@novasbe.pt Professor at Nova School of Business \& Economics - Lisboa, Portugal

\section{BERNARD LECA}

\section{leca@essec.edu}

Professor at École Supérieure des Sciences Économiques et Commerciales, Business School Cergy-Pontoise, France
We are at Paris-Dauphine University on a warm afternoon of May 2011. A small group of scholars and PhD students are currently occupying two rooms to start a new and informal experience together. Their wish is to create an occasion for discussing, from a multidisciplinary perspective, a number of emergent topics and their interconnection with technology and practices "in the context of organizing." Among the emergent topics, some terms appear prominent, like material, materiality, sociomateriality, and performativity. This first meeting sowed the seeds for the launching of a series of annual workshops under the name OAP: Organizations, Artifacts, and Practices. The purpose of this introductory article is to present the OAP community to the RAE readers in order to initiate a dialogue and eventually integrate Latin American voices in the so-called materiality turn. As the ninth OAP workshop will take place in São Paulo in 2019, this encounter is timely.

\section{REDRAWING THE OAP PATH: INFORMAL WORKSHOPS AND INSTIGATING BOOKS}

From the pioneer meeting in 2011 - the theme of which was social networks and artifacts in organizations - six other annual workshops took place in different cities from 2012 to 2017. The themes selected to brand each workshop attest to the vitality and intellectual curiosity of the OAP participants: materiality and space in management and organizational studies (Paris, 2012); time, history, and materiality (London, 2013); rules, regulation, and materiality (Rome, 2014); managerial techniques and materiality (Sydney, 2015); materiality and institutions (Lisbon, 2016); and collaboration and materiality (Singapore, 2017). Around 50 papers were typically presented each year. At least two more workshops are planned for the two next years: rematerializing organizations in the digital age will be the theme for Amsterdam, forthcoming in 2018, and politics and societal issues will warm the conversations in São Paulo in 2019.

In addition to being the founders of OAP, two scholars - François-Xavier de Vaujany (ParisDauphine) and Nathalie Mitev (King's College London) - have been playing a key role in nourishing the OAP community with books and special issues that document the evolving debates around materiality and sociomateriality. With the collaboration of other OAP fellows, François-Xavier and Nathalie have already organized and published three books - Materiality \& Space (2013); Materiality \& Time (2014), with a more historical perspective on organization, artefacts, and practices; and Materiality, Rules \& Regulations (2015), targeting new trends in management and organization studies. Two new books 
are in press: Materiality \& Managerial Techniques and Materiality \& Institutions. The current special issue at RAE was conceived during the fifth OAP workshop taking place in Lisbon, when we had for the first time an "Ibero track" welcoming articles written in Portuguese and Spanish. In addition, there is a current special issue with Organization Studies, and another one in planning. This impressive academic production serves to consolidate the position and contribution - both conceptual and empirical - of OAP as an influential research movement.

Some "convictions" are shared by OAP supporters regarding the nature and spirit of OAP workshops. They express that "knowledge should be free for and between academics"; therefore, the annual meetings have been promoted with no fees and no need of any kind of formal affiliation and in a spirit of open knowledge (OAP proceedings are free and easy to access). The idea is to collectively organize each year an independent event, quite informal, based on conviviality and openness. OAP supporters also have a shared wish not to grow and are not concerned with "continuity" in the long term. They could even envisage that OAP would just disappear in the next few years or, more likely, that it would be transformed into another thing, or other things. This fragility has been paradoxically a strong source of renewal - and continuity.

OAP encourages the participation of scholars from various disciplines. In addition to management and organization studies, it welcomes sociology, political science, linguistics, ergonomics, history, anthropology, philosophy, and psychology, among others. However, such openness to a diversity of perspectives does not mean a lack of coherence in terms of ontological and theoretical foundations. The main sources of conceptual influence come from somehow interconnected and dialogical lenses, inspired by phenomenology, pragmatism, post-structuralism, post-Marxism and critical realism, to cite a few. More importantly, most OAP fellows have been drawing their ideas within or inspired by the field of science and technology studies, popularly known as "STS." This field of research (Jasanoff et al., 2001; see also Kreimer, 2007; Harding, 2011) has grown over the last 30 years or so and has influenced many areas, including management and organization studies (e.g., Grint \& Woolgar, 1997; Czarniawska-Joerges, 1995). It represents a confluence of various research areas with the aim of understanding science and technology as socially embedded. Starting in the mid-1980s, it succeeded in adding technology to the range of interests in science (the "technology turn"), and it combines history; sociology and anthropology of technology; philosophy of science; societal issues of science and technology; and science, engineering, and technology policies. Its main constructs are the social construction of technology (Bijker, Hughes, \& Pinch, 1987), the techno-social (Callon, 1990; Latour, 2005), technoscience (Anderson, 2002), alternative modernity (Feenberg, 1995), the pace of innovation (Goldman, 1989), and deliberative democracy (Jasanoff, 2003).

\section{OAP AND THE “MATERIALITY” TURN}

OAP might be seen as one more movement taking part in the materiality turn. Scholars use the term "turn" to refer to intellectual movements that share a given direction of research, focusing on some coherent sets of theories, concepts, and ideas. Often related to broader points of bifurcation in the social sciences and humanities, a number of turns might be identified in organization studies, including the linguistic turn (Alvesson \& Karreman, 2000; Deetz, 2003), the pragmatic turn (Bernstein, 2010; Martela, 2015), and the practice turn (Feldman \& Orlikowski, 2011; Knorr-Cetina, Shatzki, \& Von Savigny, 2005), to mention a few.

The so-called materiality turn is one of these major turns. It emerged in the 1990s, when the "modes of existence of things" were called into question by elements like the digitalization of societies and organizations (Van Dijk, 2012); the disembodiment of agency (Hayles, 1999); and the increasingly distributed modalities of collective activity supported by mobile technologies, digital nomadism, and collaborative platforms and spaces (Engeström et al., 1999; Turner et al, 2006). Within the materiality turn, we refer to an embedded stream that focuses more specifically on the "socio"-materiality. In management and organization studies, "sociomaterial" scholars have attempted to overcome the dichotomy between the social and material worlds by concentrating on the practices within organizations, practices that are constituted by, but also produce, material and social dynamics. According to Orlikowski (2007, p. 1435), we have "overlooked the ways in which organizing is bound up with the material forms and spaces through which humans act and interact." Seminal influences might be found among the writings of Suchman (1987), Pickering (1995), Latour (2005), Orlikowski (2005), Leonardi (2013), and Barad (2013), whose contributions have provided some of the keywords found in the sociomaterial vocabulary: material, materiality, devices, apparatuses, intraaction, affordance, entanglement, and performativity.

To sum up, the concern with sociomateriality brings the promise of better capturing the richness of novel, relational, indeterminate, and always emergent contemporary organizing where the social and the material cannot be separated. Examples of key issues discussed in management and organization 
studies from a sociomaterial perspective relate to the practical entanglement of material and social elements (Orlikowski, 2007); the problem of ethics in a complex world and the issue of control and moral delegation in a more digital world (Dale, 2005; Introna, 2013); materiality and regulation in a post-crisis economy (Wasserman \& Frenkel, 2011); or the temporal, spatial, and material dimensions of legitimacy, institutional logics, and legitimation (Jones et al., 2013).

\section{Latin American voices joining the sociomaterial debate}

By exploring the relationships between organizations, artifacts, and practices, OAP scholars often focus on work and organizing practices, practices that are becoming more and more digital, distributed, community-oriented, open, and collaborative. Although relevant to increase our understanding of our contemporary social world, the persistent focus on organizational practices might be seen as a limitation to be overcome by the OAP community. In addition, very often the discussions hitting the rooms of OAP workshops are highly abstract, carrying the risk of losing the attention and interest of researchers and PhD students looking for more "concrete" insights. Debates around the meaning of relational ontology and the nature of agency of humans and materials have consumed countless hours of discussion and writing (Mutch, 2013; Kautz \& Jensen, 2013; Lemonnier, 2017). We are not saying that such philosophical discussions are without importance. They have namely resulted in the distinction between different ontological stances stressing the interpenetration of the social and the material (Introna, 2013), the irrelevance of the terms themselves (Lorino, 2013), the necessity of keeping a focus on material and social "domains" or "agencies" (Mutch, 2013), or the necessity of moving to other interrelated debates such as transcendental versus immanent views of processes and sociomaterial practices (de Vaujany \& Mitev, 2016). However, we are arguing that, in the sense of urgency that we can feel today regarding a politically unstable, environmentally threatened, socially unfair, and economically unbalanced among classes and countries, we could ask ourselves what kind of relevant contribution sociomateriality research could bring to a better world. This sense of urgency could be considered even greater in Latin America, and particularly huge in Brazil, given the prolonged institutional and economic crisis the country is going through, providing a rich environment for sociomaterial analysis. Paradoxically, our insight is that these projections into more concrete societal and political debates will be a way to go beyond pointless philosophical discussions for the sake of philosophical debates and could strengthen sociomateriality and the materiality turn.

As we are planning to bring an OAP workshop to Brazil in 2019, it is timely to broaden the focus from what is happening in organizations to what is shaking and destabilizing our communities and society, integrating a number of social and political issues that could be also seen as "sociomaterial," such as the politics of materiality and embodiment (Irni, 2013; Dale, 2005); the politics of performativity (Boucher, 2006); or the broader issues of organizing, infrastructures, and practices interrelated to the rising new world of work and the sharing economy.

Another interesting point that the integration of Latin American voices to the OAP debates could bring is a potential critique of dominant Euro-modern ways of thinking about academic production and consumption. The possibility of decentering the prevailing academic discourse and envisioning new possibilities of argumentation could reorient imagination and practices. For instance, the strong stream associated with post-colonial and post-development thinking provides a view of profound and radical delusion and disappointment with the exploitative thinking paradigm that has dominated Europe and the Americas for the last 500 years, based on the processes of colonization, imperialism, neoliberalism, and market-based globalization with a focus on economic growth despite human well-being (Esteva 1992; Escobar, 2011; Gomes, 2012). This dominance also characterizes academia (Alves \& Pozzebon, 2013; Alcadipani et al., 2013). Not only for language reasons, but mainly due to experiential and historical interpretive frames that are quite distinct, researchers operating in the so-called developed regions dominate the intellectual debate and impose their rules and vocabulary. We are not romanticizing alternative, local, and indigenous discourses - with their own situated understandings, shaped and developed in accordance with their particular historical and cultural experiences - but just outlining their barriers to being heard by "global" Western-based researchers and to escaping their subaltern condition.

Take as an example the previously mentioned ontological discussion. Sociomateriality is commonly associated with relational ontology. The ontology of post-colonial thinking that recovers the ontology of indigenous communities - is also relational, but one that goes further, one that not only attributes agency to humans and non-humans but that gives privileged status to nature (Perera, 2015). It, therefore, involves a paradigm shift that questions the discontinuity between humans and all other forms. It also deconstructs a basic feature of modern ontology, wherein a separate self - or the "individual" of liberal theory - is distinguished from community and nature. 
This disruption of the Western-based paradigm of conceiving individuals and organizations as the legitimate entities of society is one of the most original debates that Latin American voices might bring to OAP. When the rights of nature are accorded their recognized place, individuals become a non-dissociable part of plural, multi-epistemic communities. Growth and success are replaced by concepts like "living well," which translates as buen vivir, or, to employ Andean indigenous words, sumac kawsay in Quechua and suma qamana in Aymara. In such ways of living, the "small," the "inefficient," and the "unproductive" are not only appreciated but seen as necessary (Hart, 2010). Villalba (2013) explains the complexity and plurality lying behind buen vivir proposals, where the ontology is relational; the notion of time as linear and sequential is meaningless; the political way of interacting is based on consensus and self-management; and the spiritual and sacred are part of daily life. Although this is just an example, it illustrates the kind of debate the integration of Latin American voices could bring to the OAP debates and the materiality turn at large.

\section{THE ARTICLES OF THIS SPECIAL ISSUE}

Three papers were selected for this special issue, two of them previously presented in the sixth OAP workshop, held in Lisbon in June 2016. These three papers take different theoretical approaches, distinct methods, and diversified perspectives of sociomateriality, covering co-location spaces, educational activities, and managerial accounting.

Willems and van Marrewijk (2017) address territorial aspects that produce co-location in a spatial setting where collaboration is "demanded." Based on a longitudinal ethnographic study in the Dutch railway system, the authors show how space emerges in the interplay of maps as well as territories and co-location as well as "dis-location." Experiences of employees from seven major railway organizations co-located in the national control center show how several territorial practices were developed to undermine and subvert the initial intentions behind the design of the co-located building. The paper discusses how sociomaterial collaborative practices presented in this case transcended territories or resurrected the boundaries between them.

Lemos (2017) discusses how a school, located in a favela in São Paulo, deals with a flood issue by integrating its educational activities into the community activities. Based on a notion of collaborative agency and formative intervention, the author conducts an analysis of categories of description and argumentation, contributing to the scrutiny of different voices and activities relating to school and community. Those activities provided joint objects, or artefacts, that enriched the sociomateriality in the educational management organization. The paper shows how educational management activities can lead to the transformation of the school and its surroundings by bringing teachers to work collaboratively to reorganize their curricula according to the reality in which the school is immersed.

Russo and Guerreiro (2017) present a context of organizational management aimed at deepening knowledge in the field of managerial accounting. Based on the perception of managers about the sociomateriality of management accounting practices, the authors propose a construct that considers the conflicts between ceremonial institutional logic and instrumental institutional logic. The analysis of data collected from more than one hundred large non-financial organizations operating in Brazil shows that accounting practices in these organizations are being primarily used as problem-solving technologies that contribute to changing the context in which they are inserted.

\section{REFERENCES}

Alcadipani, R., Dar, S., Gantman, E., \& Yousfi, H. (2013). Challenging Anglo-Saxon dominance in management and organizational knowledge. RAE-Revista de Administração de Empresas, 55(2), 126 129. doi:10.1590/So034-759020150202

Alves, M. A., \& Pozzebon, M. (2013). How to resist linguistic domination and promote knowledge diversity? RAE-Revista de Administração de Empresas, 53(6), 629-633. doi:10.1590/So034-759020130610

Alvesson, M., \& Karreman, D. (2000). Varieties of discourse: On the study of organizations through discourse analysis. Human Relations, 53(9), 1125-1149. doi:10.1177/0018726700539002

Anderson, W. (2002). Introduction: Postcolonial technoscience. Social Studies ofScience,32(5-6),643-658.doi:10.1177/030631270203200502

Barad, K. (2013). Ma(r)king time: Material entanglements and rememberings: Cutting together-Apart 1. In P. R. Carlile, D. Nicolini, A. Langley, \& H. Tsoukas (Eds.), How matter matters: Objects, artifacts, and materiality in organization studies (pp. 16-31). Oxford, UK: Oxford University Press.

Bernstein, R. J. (2010). The pragmatic turn. Cambridge, US: Polity Press.

Bhaskar, R. (1979, 2014). The possibility of naturalism: A philosophical critique of the contemporary human sciences. London, UK: Routledge.

Bijker, W. E., Hughes, T. P., \& Pinch, T. J. (1987). The social construction of technological systems: New directions in the sociology and history of technology. Cambridge, US: MIT Press.

Boucher, G. (2006). The politics of performativity: A critique of Judith Butler. Parrhesia: A Journal of Critical Philosophy, (1), 112-141.

Callon, M. (1990). Techno-economic networks and irreversibility. The Sociological Review, 38(S1), 132-161. doi:10.1111/j.1467-954X.1990. tbo3351.x 
Carlile, P. R. \& Langley, A. (Eds.) (2013). How matter matters: Objects, artifacts, and materiality in organization studies (Vol. 3). Oxford, UK: Oxford University Press.

Czarniawska-Joerges, B. (1995). Narration or science? Collapsing the division in organization studies. Organization, 2(1), 11-33. doi:10.1177/135050849521002

Dale, K. (2005). Building a social materiality: Spatial and embodied politics in organizational control. Organization, 12(5), 649-678. doi:10.1177/1350508405055940

de Vaujany, F.-X. \& Mitev, N. (2013). Materiality and Space: Organizations, artefacts and practices. Basingstoke, UK: Palgrave Macmillan UK.

de Vaujany, F.-X. \& Mitev, N. (2015). The post-Macy paradox, information management and organising: Good intentions and a road to hell? Culture and Organization, 23(5), 379-407. doi:10.1080/14759551.20 15.1103242

de Vaujany, F.-X. \& Mitev, N. (2016). Introduction au tournant matériel. In F.-X. de Vaujany, A. Hussenot, \& J.-F. Chanlat (Eds.), Les théories des organisations. Paris, France: Economica.

Deetz, S. (2003). Reclaiming the legacy of the linguistic turn. Organization, 10(3), 421-429. doi:10.1177/13505084030103002

Engeström, Y., Miettinen, R., \& Punamäki, R. L. (1999). Perspectives on activity theory. Cambridge, UK: Cambridge University Press.

Escobar, A. (2010). Latin America at a crossroads?: Alternative modernizations, post-liberalism, or post-development? Cultural Studies, 24(1), 1-65. doi:10.1080/09502380903424208

Escobar, A. (2011). Encountering development: The making and unmaking of the Third World. Princeton, US: Princeton University Press.

Esteva, G. (1992). Development. In Sachs, W. (Ed.), The development dictionary: A guide to knowledge as power, $2^{\text {nd }}$ ed. London, UK: Zed Books.

Feenberg, A. (1995). Alternative modernity: The technical turn in philosophy and social theory. Berkeley, US: University of California Press.

Feldman, M. S. \& Orlikowski, W. J. (2011). Theorizing practice and practicing theory. Organization Science, 22(5), 1240-1253. doi:10.1287/orsc.1100.0612

Goldman, S. L. (1989). No innovation without representation: Technological action in a democratic society. University Park, US: Pennsylvania State University.

Gomes, A. (2012). Alter-Native 'development': Indigenous forms of social ecology. Third World Quarterly, 33(6), 1059-1073. doi:10.108 o/01436597.2012.681491

Grint, K., \& Woolgar, S. (1997). The machine at work: Technology, work and organization. Cambridge, US: Polity Press.

Harding, S. (Ed.). (2011). The postcolonial science and technology studies reader. Durham, US: Duke University Press.

Hart, M. A. (2010). Indigenous worldviews, knowledge, and research: The development of an indigenous research paradigm. Journal of Indigenous Voices in Social Work, 1(1), 1-16.

Hayles, K. (1999). How we became posthumans. Chicago, US: University of Chicago Press.
Introna, L. D. (2013). Epilogue: Performativity and the becoming of sociomaterial assemblages. In F.-X. de Vaujany \& N. Mitev (Eds.), Materiality and space: Organizations, artefacts and practices (pp. 330-342). Basingstoke, UK: Palgrave Macmillan UK.

Irni, S. (2013). The politics of materiality: Affective encounters in a transdisciplinary debate. European Journal of Women's Studies, 2o(4), 347-360. doi:10.1177/1350506812472669

Jasanoff, S. (2003). Technologies of humility: Citizen participation in governing science. Minerva, 41(3), 223-244. doi:10.1023/A:1025557512320.

Jasanoff, S., Markle, G. E., Peterson, J. C., \& Pinch, T. (Eds.). (2001). Handbook of Science and Technology Studies. Thousand Oaks, US: Sage Publications.

Jones, C., Boxenbaum, E., \& Anthony, C. (2013). The immateriality of material practices in institutional logics. Research in the Sociology of Organizations, 39A, 51-75. doi:10.1108/S0733 558X(2013)0039A\&Bo06

Kautz, K. \& Jensen, T. B. (2013). Sociomateriality at the royal court of IS: A jester's monologue. Information and Organization, 23(1), 15-27. doi:10.1016/j.infoandorg.2013.01.001

Knorr-Cetina, K. K., Schatzki, T. R., \& Von Savigny, E. (Eds.). (2005). The practice turn in contemporary theory. London, UK: Routledge.

Kreimer, P. (2007). Estudios sociales de la ciencia y la tecnología en América Latina: ¿para qué?, ¿para quién? Redes, 13(26), 55-64.

Latour, B. (2007). Can we get our materialism back, please? Isis, 98(1), 138-142. doi:10.1086/512837

Latour, B. (2014). Technical does not mean material. Journal of Ethnographic Theory, 4(1), 507-510. doi:10.14318/hau4.1.033

Latour, B. (2005). Reassembling the Social - An introduction to actornetwork-theory. Oxford, UK: Oxford University Press.

Lemonnier, P. (2017). Shall we just call them sociomaterial black boxes or take a peek inside? An anthropologist's impressionist remarks. In N. Mitev, A. Morgan-Thomas, P. Lorino, F.-X. de Vaujany, \& Y. Nama (Eds.), Materiality and managerial techniques: New perspectives on organizations, artefacts and practices. Basingstoke, UK: Palgrave Macmillan.

Lemos, M. (2017). Collaborative agency in educational management: Constructing a joint object for school and community transformation. RAE-Revista de Administração de Empresas, 57(6), 555-566. doi:10.1590/So034-759020170604.

Leonardi, P. M. (2013). Theoretical foundations for the study of sociomateriality. Information and Organization, 23(2), 59-76. doi:10.1016/j.infoandorg.2013.02.002

Lorino, P. (2013). Management Systems as organizational 'architextures'. In F.-X. Vaujany \& N. Mitev (Eds.), Materiality and space: Organizations, artefacts and practices (pp. 62-95). Basingstoke, UK: Palgrave Macmillan UK.

Martela, F. (2015). Fallible inquiry with ethical ends-in-view: A pragmatist philosophy of science for organizational research. Organization Studies, 36(4), 537-563. doi:10.1177/0170840614559257

Mutch, A. (2013). Sociomateriality-Taking the wrong turning? Information and Organization, 23(1), 28-40. doi:10.1016/j. infoandorg.2013.02.001 
Orlikowski, W. J. (2007). Sociomaterial practices: Exploring technology at work. Organization Studies, 28(9), 1435-1448. doi:10.1177/0170840607081138

Perera, V. (2015). Engaged universals and community economies: The (human) right to water in Colombia. Antipode, 47(1), 197-215. doi:10.1111/anti.12097

Pickering, A. (2010). The mangle of practice: Time, agency, and science. Chicago, US: University of Chicago Press.

Russo, P. T., \& Guerreiro, R. (2017). A percepção sobre a sociomaterialidade das práticas de contabilidade gerencial. RAERevista de Administração de Empresas, 57(6), 567-584. doi:10.159o/ So034-759020170605.

Turner, W., Bowker, G., Gasser, L., \& Zacklad, M. (2006). Information infrastructures for distributed collective practices. Computer Supported Cooperative Work (CSCW), 15(2-3), 93-110. doi:10.1007/ s10606-006-9014-3
Van Dijk, J. (2012). The network society. Thousand Oaks, US: Sage Publications.

Wasserman, V. \& Frenkel, M. (2011). Organizational aesthetics: Caught between identity regulation and culture jamming. Organization Science, 22(2), 503-521. doi:10.1287/orsc.1100.0583

Willems, T., \& van Marrewijk, A. (2017). Building collaboration? From colocation to dis-location, an ethnographic study in a railway control center. RAE-Revista de Administração de Empresas, 57(6), 542-554. doi:10.1590/So034-759020170603.

Shaffer, P. (2012). Post-development and poverty: An assessment. Third World Quarterly, 33(10), 1767-1782. doi:10.1080/01436597.2012.728314

Villalba, U. (2013). Buen vivir vs development: A paradigm shift in the Andes? Third World Quarterly, 34(8), 1427-1442. doi:10.1080/01436 597.2013 .831594 